\title{
Implementasi Penilaian Autentik: Model Perangkat pembelajaran dan penilaian Matematika dengan pendekatan CTL Berbasis Budaya Islam
}

\author{
1Seni Ermawati ${ }^{2}$ Syukrul Hamdi \\ ${ }^{1}$ seniermawati@gmail.com \\ Prodi Pendidikan Matematika FMIPA Universitas Hamzanwadi, Lotim, NTB \\ ${ }^{2}$ syukrulhamdi@hamzanwadi.ac.id \\ Prodi Pendidikan Matematika FMIPA Universitas Hamzanwadi, Lotim, NTB
}

\begin{abstract}
This study aims at implementing authentic assessments in mathematics learning in the classroom by developing mathematical learning and assessment tools with Islamic culture based Contextual Teaching and Learning approach that meet valid, practical, and effective requirements. The research procedure adopted the 4-D Development model, those are Defining, Planning, Developing and distributing stages. The instrument used to assist the research process consisted of (1) device validation sheet, (2) practicality questionnaire from the teacher, (3) student response questionnaire, (4) Instrument of student motivation and learning outcomes. The validity quality of learning devices meets valid criteria based on the average score of the syllabus which reaches 4.18 , lesson plan 4.18 , textbook 4.28, and the instrument meets the valid index based on the aikens formula. The practicality quality of learning devices meets practical criteria based on the assessment of practicality of the teacher in which the average score reaches 4.75 , and the response questionnaire assessment of students is 493. Based on the result of Manova test, it can be concluded that the use of Mathematics learning and assessment model with Islamic culture based Contextual Teaching and Learning approaches is effective in terms of learning outcomes and student motivation.
\end{abstract}

Keywords : Mathematics Teaching Materials, CTL based on Islamic culture, Autentic asessment

\begin{abstract}
Abstrak
Penelitian ini bertujuan untuk mengimplementasikan penilaian autentik dalam pembelajaran matematika di kelas dengan mengembangkan perangkat pembelajaran dan penilaian matematika dengan pendekatan CTL berbasis budaya Islam yang memenuhi syarat valid, praktis, dan efektif. Prosedur penelitian mengadopsi model Pengembangan 4-D yaitu tahap Pendefinisian, Perencanaan, Pengembangan, dan penyebaran. Instrument yang digunakan untuk membantu proses penelitian ini terdiri dari (1) lembar validasi perangkat, (2) angket kepraktisan dari guru, (3) angket respon peserta didik, (4) Instrumen motivasi dan hasil belajar siswa. Kualitas kevalidan perangkat pembelajaran memenuhi kriteria valid berdasarkan skor rata-rata silabus mencapai 4.18, RPP 4.18, buku ajar 4.28, dan instrumen memenuhi indeks valid berdasarkan formula aikens. Kualitas kepraktisan perangkat pembelajaran memenuhi kriteria praktis berdasarkan penilaian kepraktisan dari guru yaitu rata-rata skor mencapai 4,75, dan penilaian angket respon peserta didik mencapai jumlah skor total 493. Berdasarkan hasil uji manova dapat disimpulkan penggunaan perangkat pembelajaran dan penilaian matematika dengan pendekatan CTL berbasis budaya Islam efektif ditinjau dari hasil belajar dan motivasi siswa.
\end{abstract}

Kata kunci: Bahan Ajar Matematika, CTL berbasis budaya Islam, Penilaian Autentik 


\section{PENDAHULUAN}

Pendidikan merupakan salah satu upaya terbaik dalam meningkatkan mutu sumber daya manusia menuju era globalisasi yang penuh dengan tantangan. Melalui pendidikan para generasi penerus akan dididik untuk mengembangkan segala aspek yang dimilikinya. Amri, dkk. (2010: 1) mengatakan bahwa Pendidikan merupakan salah satu kebutuhan pokok dalam kehidupan manusia tentang bagaimana mempertahankan hidup manusia yang mengemban tugas dari sang Kholiq untuk beribadah.

Sebagai salah satu kebutuhan pokok yang sangat berpengaruh pada peradaban dan kemajuan bangsa, proses pendidikan harus dilaksanakan dengan optimal. Optimalisasi proses pendidikan dapat direalisasikan dengan memperhatikan semua aspek atau bagian penyelenggaraan pendidikan. Salah satu aspek penting yang sangat berpengaruh dalam pelaksanaan pendidikan adalah penilaian.

Penilaian merupakan proses akhir yang dilaksanakan dalam setiap proses pembelajaran. Tuntutan pelaksanaan penilaian harus berlandaskan pada penilaian yang komperehensif dan dekat dengan kehidupan peserta didik yang biasa dikenal dengan istilah penilaian autentik. Penilaian autentik adalah penilaian yang komprehensif, artinya mulai dari penilaian masukan (input), penilaian proses sampai penilaian output pembelajaran (Permendikbud Nomor 66 tahun 2013 tentang Standar Penilaian). Selain itu, Kartowagiran, Jaedun, dan Hamdi juga menjelaskan bahwa (2017) Comprehensive assessment is an assessment that includes knowledge, skills, spiritual attitudes, and social attitudes.

Penilaian autentik yang dimaksud dalam hal ini adalah implementasinya dalam penyusunan perangkat pembelajaran yang digunakan sebagai acuan pelaksanaan pembelajaran di kelas. Bagian perangkat pembelajaran dalam hal ini berhubungan dengan model penilaian, termasuk instrumen dan teknik. Dengan begitu, maka hasil pembelajaran yang dilaksanakan bisa terukur dan terealisasi dengan baik.

Salah satu lembaga sekolah yang menyediakan kebutuhan selain akademik siswa juga spiritual siswa adalah lembaga pendidikan Islam yang biasa disebut pondok pesantren. Pondok Pesantren merupakan suatu bangunan yang dijadikan tempat belajar bagi para santri (siswa) sama halnya dengan sekolah. Bedanya terletak pada fokus lembaga pendidikan tersebut. Di Indonesia terdapat banyak sekali lembaga pendidikan yang berbentuk Pondok Pesantren. Menurut Muhajir (2011: 13) mengatakan bahwa secara kuantitatif selama orde baru di Indonesia capaian peningkatan jumlah pendidikan sangat baik, yaitu terdapat 150.595 SD, 20.544 SLTP, 8.690 SLTA, dan 40 PTN. Dari semua jumlah tersebut di domisili oleh lembaga pendidikan swasta yang tentunya sebagian besar adalah lembaga pendidikan swasta yang berbentuk Pondok Pesantren. Bahkan Menag RI, Lukman Hakim Syaifuddin menyatakan bahwa "total lembaga pendidikan Islam di Indonesia sebanyak 300.270 lembaga. Bahkan capaian tersebut merupakan jumlah terbesar di dunia. Mulai dari Raudlatul Athfal hingga perguruan tinggi. Sekaligus diantaranya sebanyak 27.290 Pondok Pesantren yang tersebar diseluruh tanah air, (Senin, 
21/12/2015). Jumlah Pondok Pesantren di Lombok sangatlah banyak, khususnya di Lombok Timur. Hal ini diungkapkan oleh Kepala Depag Lombok Timur.

Matematika bukan hal yang asing bagi semua kalangan masyarakat dikarenakan kegunaannya dalam setiap aktivitas kehidupan sangatlah banyak baik kegunaan dalam kegiatan yang disadari maupun tidak disadari. Oleh karenanya matematika menjadi mata pelajaran wajib yang ada disetiap jenjang pendidikan dan setiap jurusan, tentu dengan tingkat kesulitan yang berbeda-beda dalam setiap jenjang dan jurusan yang ditekuni.

Menurut observasi yang dilakukan di Pondok Pesantren Ridlol Walidain NW Batu Bangka pada tanggal 12 Maret 2018 dan observasi yang dilakukan selama proses magang 3 di salah satu pondok pesantren di Hizbul Wathan NW Semaya yaitu pada tanggal 7 Agustus s/d 7 Oktober 2017, yang dilakukan melalui wawancara bersama siswa-siswi yang ada di Pondok Pesantren tersebut, sebagian besar mereka mengatakan bahwa matematika merupakan salah satu pelajaran yang sangat sulit dipahami, tidak sedikit dari mereka yang mengatakan bahwa pelajaran yang paling ditakuti dan dibenci adalah matematika bahkan ada siswa yang mengatakan stres ketika bertemu dengan soal-soal matematika sehingga sebagian mereka ada yang sering bolos dalam pelajaran ini. Hal ini menjadi kajian bagi penulis untuk mencari latar belakang kesulitan siswa. dan salah satu penyebab yang ditemukan adalah pemikiran siswa di pondok pensantren tentang matematika adalah bahwa matematika merupakan ilmu dunia yang tidak ada keterkaitannya dengan dunia Islam, menurut mereka bahwa matematika tidak sesuai dengan tujuan Pondok Pesantren yaitu untuk meningkatkan spiritual siswa. Jadi, salah satu cara yang harus dilakukan adalah dengan memberikan pemahaman kepada siswa tentang matematika itu sendiri dan pentingnya belajar matematika kemudian keterkaitan matematika dengan dunia Islam

Berdasarkan alasan-alasan di atas penulis mencoba mengembangkan bahan ajar yang dapat mengintegrasikan antara matematika dengan konsep Islam yaitu bahan ajar yang berbasis matematika Islami dengan harapan agar dapat meningkatkan motivasi belajar siswa pada mata pelajaran matematika sehingga hasil belajar yang menjadi tolak ukur keberhasilan siswa dapat meningkat. Utuk menunjang tujuan tersebut, dalam pembuatan bahan ajar ini penulis menggunakan metode pembelajaran Contextual Teaching and Learninng (CTL), karna metode ini erat kaitannya dengan pendekatan yang ingin dibuat. Menurut Jhonson (2002:16) "CTL is a system that stimulates the brain to weave patterns thats express meaning. CTL is a brain-compatible system of intruction that generates meaning by lingking academic content with the context of a studentd's daily life".Ungkapan tersebut menunjukkan bahwa CTL adalah sebuah sistem yang meransang otak untuk menransang pola-pola yang mewujudkan makna.

Menurut Wardoyo (2013: 53-54) Contextual Teaching and Learninng merupakan pembelajaran yang dilakukan guru dengan mengaitkan antara materi yang diajarkan dengan situasi dunia nyata dan mendorong peserta didik membuat hubungan antara pengetahuan yang dimilikinya dengan penerapannya dalam kehidupan. Baik sebagai bagian dari keluarga maupun masyarakat. Secara singkat 
Suprihatiningrum (2016: 178) mengatakan bahwa CTL merupakan pembelajaran yang dikaitkan dengan konteks kehidupan sehari-hari siswa. Pendapat tersebut diperkuat oleh Hamdi (2011) yaitu CTL merupakan konsep belajar dimana guru menghadirkan dunia nyata ke dalam kelas dan mendorong siswa untuk membuat hubungan antara pengetahuan yang dimilikinya dengan kehidupan mereka seharihari yang berbasis pada pengembang daya kritis dan nalar untuk memperoleh tambahan pengetahuan dan keterampilan dari konteks pembelajaran sesuai dengan materi yang dicanangkan.Metode ini dapat secara tidak lansung menarik perhatian siswa untuk mencari manfaat dari apa yang dipelajari dalam kehidupannya seharihari. Metode ini akan membuat siswa berfikir bagaimana mengintegrasikan antara matematika dengan apa yang ditemukan dalam kehidupannya sehari-hari. Jadi, dengan metode belajar seperti ini yaitu menghubungkan pengetahuan dengan kehidupan sehari-hari anak dan psikologisnya akan mampu membuat siswa lebih tertarik dengan pelajaran yang dipelajari

Dengan berbagai ulasan tersebut, metode ini dipilih sebagai bahan penelitian dengan harapan melalui metode ini siswa dapat membuat hubungan antara matematika dengan kehidupan yang bernuansa Islami yaitu pembelajaran dengan metode CTL berbasis Islami. Maksud dari CTL berbasis matematika Islami adalah menghubungkan pengetahuan siswa tentang matematika ke dalam kehidupan Islami. Yaitu memecahkan persoalan-persoalan yang menyangkut konteks Islam dengan matematika. Dengan mengintegrasikan nilai-nilai islam dengan pendekatan CTL dalam pembelajaran matematika merupakan bagian dari upaya implementasi penilaian autentik di dalam pembelajaran yakni mulai dari pembelajaran autentik sampai perangkat penilaian berupa instrumen tes maupun non tes juga terkait dengan kehidupan peserta didik.

\section{METODE PENELITIAN}

Jenis penelitian ini adalah penelitian pengembangan. Penelitian ini mengembangkan produk perangkat pembelajaran dan penilaian matematika dengan pendekatan Contextual Teaching and Learning (CTL) berbasis budaya Islam sebagai wujud implementasi penilaian autentik. Model pengembangan yang digunakan dalam penelitian ini adalah model 4-D.

Prosedur pengembangan bahan ajar model 4-D melalui 4 tahap yaitu Pendefinisian (Define), perancangan (Design), pengembangan (Develove), dan penyebaran (Disseminate). Pada tahap Define peneliti melakukan analisis-analisis untuk menemukan masalah dan solusi apa yang dapat diberikan, diantranya peneliti melakukan Analisis Awal Akhir, Analisis Siswa, Analisi Tugas, Analisis Konsep, dan Perumusan Tujuan Pembelajaran dan penilaian.

Pada tahap Design, peneliti menyiapkan prototype perangkat pembelajaran dan penilaian yang akan dikembangkan berupa silabus, RPP, Buku Ajar dan Instrumen peniliaian aspek sikap yaitu angket motivasi dan instrumen untuk mengukur pengetahuan yaitu instrumen tes hasil belajar. Bahan ajar yang dihasilkan pada tahap ini disebut sebagai draf I. Beberapa hal yang dilakukan pada tahap ini yaitu Pemilihan Media, Pemilihan Format, dan Rancangan Awal. 
Setelah draf 1 jadi, tahap selanjutnya yaitu melakukan pengembangan (Develop) berdasarkan uji validasi ahli yang dilakukan setelah draf 1 jadi. Hasil validasi ahli tersebut kemudian di analisis dan direvisi sesuai saran validator. Adapun anlisis yang digunakan untuk membuktikan validitas instrumen atau perangkat penilaian menggunakan formula aikens, dan yang digunakan untuk melihat kevalidan dan kepraktisan perangkat pembelajaran adalah dengan cara menghitung jumlah validasi dari validator secara keseluruhan, kemudian menghitung nilai rata-rata hasil tersebut kemudian di konversikan dengan tabel klasifikasi analisis kevalidan berikut.

Tabel 1. Klasifikasi Analisis Kevalidan

\begin{tabular}{cc}
\hline Rata-Rata Skor Total & Klasifikasi \\
\hline $4,2 \leq \bar{x} \leq 5,0$ & Sangat baik \\
$3,4 \leq \bar{x} \leq 4,2$ & Baik \\
$2,6 \leq \bar{x} \leq 3,4$ & Cukup \\
$1,8 \leq \bar{x} \leq 2,6$ & Kurang \\
$1,0 \leq \bar{x} \leq 1,8$ & Sangat kurang \\
\hline
\end{tabular}

Hasil revisi disebut draf 2. Draf 2 tersebut yang di uji cobakan ke lapangan.Uji coba lapangan (field trial) pada penelitian ini dilakukan disalah satu pondok pesantren yang ada di Lombok Timur yakni Pondok Pesantren Hizbul Wathan NW. Sedangkan untuk sasaran subjek penelitian ini adalah siswa-siswi kelas VII MTs. untuk penelitian ini peneliti menggunakan 2 kelas yaitu kelas eksperimen dan kelas kontrol.

Dalam proses uji coba lapangan dilakukan analisis keprraktisan. Adapun Intrumen yang digunakan dalam penelaian kepraktisan bahan ajar yang dikembangkan adalah menggunakan angket yaitu Angket kepraktisan dari Guru dan Angket Respon Peserta Didik. Hasil angket tersebut kemudian di analisis dan dikonversikan dengan table Klasifikasi Analisis Kepraktisan berikut. Produk yang dikembangkan dikatakan valid dan praktis jika minimal klasifikasi yang dicapai adalah baik.

Tabel 2. Klasifikasi Analisis Kepraktisan

\begin{tabular}{cc}
\hline Rata-rata skor total & Klasifikasi \\
\hline 409.6 s/d 512 & Sangat baik \\
307,2 s/d 409.6 & Baik \\
204,8 s/d 307,2 & Cukup \\
102,4 s/d 204,8 & Kurang \\
0 s/d 102,4 & Sangat kurang \\
\hline
\end{tabular}

Data-data hasil uji coba lapangan kemudian dianalisis untuk mengetahui keefektifan perangkat pembelajaran dan penilaian. Analisis data tersebut dilakukan untuk melihat apakah ada pengaruh yang signifiikan terhadap perangkat pembelajaran dan penilaian yang dikembangkan. Analisis data digunakan untuk 
melihat keefektifan perangkat pembelajaran dan penilaian menggunakan analisis MANOVA. Manova merupakan teknik analisis untuk menguji dua atau lebih variable dependen metrik dengan variable independen non metrik (Indrawan dan Yaniawati, 2014:180). Sebelum analisis manova sebelumnya data yang dihasilkan di uji kenormalan dan tingkat homogenitasnya karena syarat manova adalah data harus berdistribusi normal dan homogen.

\section{HASIL PENELITIAN DAN PEMBAHASAN}

Hasil pengembangan dalam penelitian ini adalah perangkat pembelajaran menggunakan pendekatan CTL Berbasis budaya Islam. Perangkat pembelajaran dan penilaian yang dikembangkan berupa silabus, RPP, Bahan ajar, dan instrumen penilaian sesuai prosedur pengembangan dengan model 4-D. Hasil penelitian yang dilakukan terhadap perangkat pembelajaran yang dikembangkan dapat dilihat pada tabel berikut.

Tabel 3. Hasil Analisis Validasi Perangkat Pembelajaran

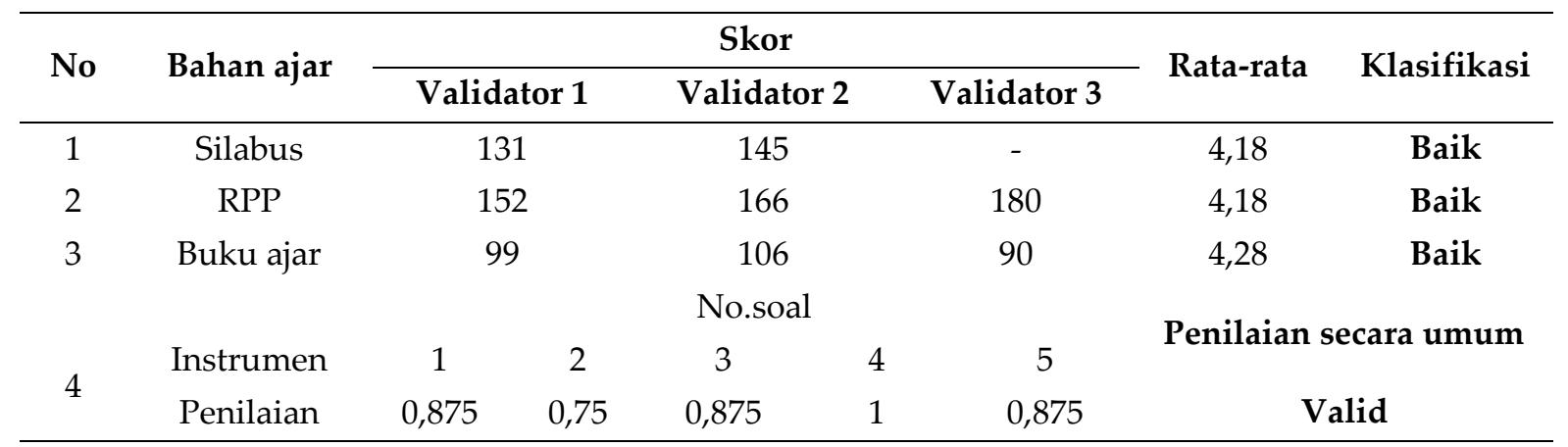

Hasil tabel 3 terlihat bahwa validasi silabus dari ketiga validator mencapai rata-rata 4,18 yang memenuhi klasifikasi baik. Validasi RPP rata-ratanya mencapai 4,18 yang memenuhi klasifikasi baik. Validasi buku ajar rata-ratanya mencapai 4,28 yang memenuhi klasifikasi baik. Dan instrumen penilaian menunjukkan persentase yang dicapai masing-masing validator memenuhi kriteria valid berdasarkan penghitungan menggunakan formula aiken yaitu 0,88. Dengan demikian dapat disimpulkan menurut para ahli perangkat pembelajaran dan penilaian telah memenuhi kriteria valid.

Tabel 4. Hasil Analisis Kepraktisan Perangkat Pembelajaran

\begin{tabular}{clcc}
\hline No & & Kepraktisan dari Guru & Angket Respon Peserta Didik \\
\hline 1 & Jumlah Responden & 1 & 32 \\
2 & Jumlah Pertanyaan & 8 & 17 \\
3 & Jumlah Skor & 38 & 493 \\
4 & Nilai Rata-Rata Skor & 4,75 & - \\
5 & Klasifikasi & Sangat Baik & Sangat Baik \\
\hline \multicolumn{2}{l}{ Hasil tabel } & 4 terlihat bahwa rata-rata & penilaian kepraktisan dari guru
\end{tabular}
mencapai 4,75 yang memenuhi klasifikasi sangat baik. Dan angket respon peserta didik memperoleh jumlah skor mencapai 493 yang memenuhi klasifikasi Sangat baik. Dari hal tersebut dapat disimpulkan perangkat pembelajaran telah memenuhi kriteria praktis. 
Untuk tingkat reliabelitas perangkat penilaian yaitu instrumen tes dan angket motivasi ditemukan bahwa angket motivasi mendapatkan hasil estimasi reliabiltas sebesar 0.96 dan instrumen tes hasil belajar matematika mendapat hasil estimasi reliabilitas sebesar 0.79 . Setelah data berdistribusi normal dan homogeny serta reliabel maka bisa dilakukan uji $t$. Hasil uji t dapat dilihat pada tabel berikut.

Tabel 5. Box's Test of Equality of Convariance Matrices

\begin{tabular}{cc}
\hline Box's $\boldsymbol{M}$ & 1,234 \\
F & 0,396 \\
df1 & 3 \\
df2 & 25318818.574 \\
Sig. & 0,756 \\
\hline
\end{tabular}

Dari tabel 5, terlihat bahwa signifikansi yang diperoleh 0,756 lebih besar dari 0.05 ini menunjukkan adanya kesamaan variable dependen menunjukkan adanya kesamaan varian kovarian pada variable bebas.

Tabel 6. Levense's Test Of Equality Of Error Vaiances

\begin{tabular}{ccccc}
\hline & F & df1 & df2 & Sig. \\
\hline Hasil Belajar & 1,114 & 1 & 57 & 0,296 \\
Motivasi Belajar & 0,068 & 1 & 57 & 0,795 \\
\hline
\end{tabular}

Dari tabel 6, terlihat bahwa signifikansi yang diperoleh 0,296 dan 0,795 lebih besar dari 0.05 ini menunjukkan adanya kesamaan variable dependen menunjukkan adanya kesamaan varian kovarian pada variable bebas.

Tabel 7. Multivariat Test

\begin{tabular}{|c|c|c|c|c|c|c|}
\hline \multicolumn{2}{|c|}{ Effect } & Value & $\mathbf{F}$ & $\begin{array}{c}\text { Hypothesis } \\
\text { df }\end{array}$ & Error df & Sig. \\
\hline Intercept & $\begin{array}{c}\text { Hotelling's } \\
\text { Trace }\end{array}$ & 167,583 & $4,692,337$ & 2,000 & 56,000 & 0,000 \\
\hline MODEL & $\begin{array}{l}\text { Hotelling's } \\
\text { Trace }\end{array}$ & 0.5 & 14.002 & 2 & 56 & 0,000 \\
\hline
\end{tabular}

Adapun signifikansi yang diperoleh pada kolom Hotelling's Trace adalah 0,000 lebih kecil dari 0.05 ini menunjukkan adanya perbedaan pada kelas kontrol dan kelas eksperimen. Untuk mengkonfirmasi hasil Manova, peneliti analisis secara terpisah menggunakan independent sample t-test dengan hasil sebagai berikut. 
Tabel 8. Hasil Uji T Hasil Belajar

\begin{tabular}{|c|c|c|c|c|c|c|c|c|}
\hline \multicolumn{9}{|c|}{ Independent Samples Test } \\
\hline & & \multicolumn{7}{|c|}{ t-test for Equality of Means } \\
\hline & & \multirow[t]{2}{*}{$\mathrm{T}$} & \multirow[t]{2}{*}{$\mathrm{df}$} & \multirow{2}{*}{$\begin{array}{l}\text { Sig, }(2- \\
\text { tailed })\end{array}$} & \multirow{2}{*}{$\begin{array}{c}\text { Mean } \\
\text { Difference }\end{array}$} & \multirow{2}{*}{$\begin{array}{l}\text { Std, Error } \\
\text { Difference }\end{array}$} & \multicolumn{2}{|c|}{$\begin{array}{c}95 \% \text { Confidence Interval } \\
\text { of the Difference }\end{array}$} \\
\hline & & & & & & & Lower & Upper \\
\hline HASIL & $\begin{array}{c}\text { Equal variances } \\
\text { assumed }\end{array}$ & 2,388 & 57 & 0,020 & 16,50463 & 6,91242 & 2,66275 & 30,34651 \\
\hline BELAJAR & $\begin{array}{l}\text { Equal variances } \\
\text { not assumed }\end{array}$ & 2,416 & 56,934 & 0,019 & 16,50463 & 6,83072 & 2,82601 & 3018324 \\
\hline
\end{tabular}

Dari tabel di atas, terlihat bahwa signifikansi yang diperoleh 0,020 dan 0.019 lebih kecil dari 0.05 ini menunjukkan bahwa perangkat pembelajaran dan penilaian yang dikembangkan lebih efektif dari perangkat yang dibuat guru dilihat dari tes hasil belajar.

Tabel 9. Hasil Uji T Angket Motivasi Belajar

\begin{tabular}{|c|c|c|c|c|c|c|c|c|}
\hline \multicolumn{9}{|c|}{ Independent Samples Test } \\
\hline & & \multicolumn{7}{|c|}{ t-test for Equality of Means } \\
\hline & & \multirow[t]{2}{*}{$\mathrm{T}$} & \multirow[t]{2}{*}{ Df } & \multirow{2}{*}{$\begin{array}{l}\text { Sig, }(2- \\
\text { tailed })\end{array}$} & \multirow{2}{*}{$\begin{array}{c}\text { Mean } \\
\text { Difference }\end{array}$} & \multirow{2}{*}{$\begin{array}{l}\text { Std, Error } \\
\text { Difference }\end{array}$} & \multicolumn{2}{|c|}{$\begin{array}{c}95 \% \text { Confidence Interval } \\
\text { of the Difference }\end{array}$} \\
\hline & & & & & & & Lower & Upper \\
\hline \multirow{4}{*}{$\begin{array}{l}\text { MOTIVASI } \\
\text { BELAJAR }\end{array}$} & $\begin{array}{c}\text { Equal } \\
\text { variances }\end{array}$ & 4,275 & 57 & 0,000 & 7,29977 & 1,70770 & 3,88017 & 10,71937 \\
\hline & assumed & & & & & & & \\
\hline & Equal & & & & & & & \\
\hline & $\begin{array}{c}\text { variances not } \\
\text { assumed }\end{array}$ & 4,258 & 54,384 & 0,000 & 7,29977 & 1,71456 & 3,86284 & 10,73670 \\
\hline
\end{tabular}

Dari tabel di atas, terlihat bahwa signifikansi yang diperoleh 0,000 lebih kecil dari 0.05 ini menunjukkan bahwa perangkat pembelajaran dan penilaian yang dikembangkan lebih efektif dari perangkat yang dibuat guru dilihat dari motivasi belajar siswa.

Tahap pengembangan perangkat pembelajaran dan penilaian dimulai dari tahap pendefinisian. Tahap ini berfungsi untuk mendefinisikan syarat-syarat pengembangan perangkat pembelajaran pada materi bilangan bulat dan bilangan pecahan. Tahap ini terdiri dari analisis awal akhir, analisis siswa, analisis tugas, analisis konsep, dan perumusan tujuan pembelajaran. Analisis awal akhir bertujuan untuk mengetahui masalah yang sedang dihadapi dalam pembelajaran matematika sehingga dibutuhkan pengembangan bahan ajar. Analisis siswa dilakukan untuk mengetahui karakteristik siswa. Analisis tugas dilakukan untuk menentukan isi materi ajar secara garis besar dari Kompetensi Inti (KI) dan Kompetensi Dasar (KD). 
Analisis konsep bertujuan untuk mengidentifikasi, merinci, dan menyusun secara sistematis konsep materi bilangan bulat dan bilangan pecahan. Dan perumusan tujuan pembelajaran berfungsi untuk merumuskan tujuan yang harus dicapai siswa selama proses pembelajaran sesuai KI dan KD yang digunakan.

Tahap selanjutnya adalah perencanaan. Pemilihan media, pemilihan format, dan rancangan awal merupakan aspek utama pada tahap perencanaan. Media yang digunakan dalam penelitian ini adalah Bahan ajar yang dikembangkan yaitu Buku Ajar. Pemilihan format dalam penyusunan bahan ajar, peneliti mengkaji dan memilih format disesuaikan dengan kurikulum 2013 (K-13). Setelah itu peneliti menyusun rancangan awal Bahan ajar yang disebut sebagai draf 1 . Contoh tampilan awal setiap kegiatan terlihat pada gambar 1 berikut.
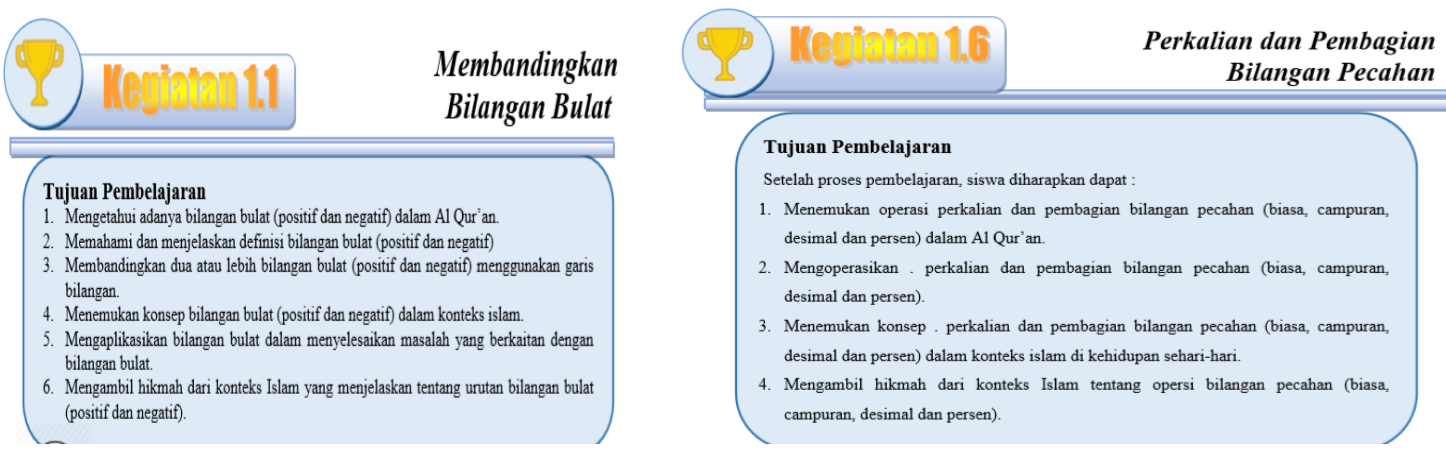

Gambar 1. Contoh tampilan awal setiap kegiatan pembelajaran

Tahap selanjutnya pengembangan. Pada tahap ini draf 1 yang sudah dibuat selanjutnya diuji kevalidan, kepraktisan, dan keefektifannya. Suatu bahan ajar dikatakan baik jika memenuhi aspek kualitas yang meliputi validitas, kepraktisan, dan keefektifan. Dalam penelitian ini uji kevalidan dilakukan oleh para ahli (validator) yang terdiri dari tiga orang. Yaitu dosen-dosen Pendidikan Matematika dan Dosen dari Bimbingan Konseling bidang agama Universitas Hamzanwadi. Hasil penilaian validasi silabus mendapat rata-rata skor mencapai 4,18 yang artinya klasifikasi mencapai baik. Hasil penilaian RPP mendapat mendapat rata-rata skor mencapai 4,18 yang artinya klasifikasi mencapai baik. Hasil penilaian buku ajar mendapat rata-rata skor mencapai 4,28 yang artinya klasifikasi mencapai sangat baik. Dan hasil penilaian instrumen penilaian menunjukkan kriteria valid. Setelah itu sebelum diujicobakan instrumen penilaian diujicobakan terlebih dahulu di kelas VII pada tempat yang berbeda untuk melihat tingkat realibilitas tes tersebut, adapun hasil realibilitas soal mencapai tingkat tinggi dengan nilai $r_{11}=0.79$ sesuai pada table klasifikasi, begitu juga dengan angket motivasi sebelum digunakan angket tersebut diujicobakan untuk melihat relibilitas intrumen dan ditemukan $\mathbf{r}_{11}=0.96$.

Selanjutnya klasifikasi perangkat pembelajaran yang memenuhi kriteria baik menunjukkan bahwa perangkat pembelajaran valid. Setelah valid perangkat pembelajaran di uji cobakan kepada 32 siswa kelas VII B sebagai kelas eksperimen dan 28 siswa kelas VII A sebagai kelas kontrol untuk melihat kepraktisan dan keefektifan perangkat pembelajaran. Perangkat pembelajaran dikatakan praktis apabila bahan ajar yang dikembangkan mudah digunakan oleh guru dan siswa sesuai aturan pakai. Data kepraktisan perangkat pembelajaran diperoleh dari 
penilaian dari guru mata pelajaran dan angket respon peserta didik. Hasil penilaian kepraktisan dari guru secara keseluruhan mendapat rata-rata skor mencapai 4,75 yang artinya klasifikasi mencapai sangat baik, dan penialain angket respon siswa mencapai jumlah total 493 yang artinya klasifikasi mencapai baik. Klasifikasi penilaian dari guru dan angket respon siswa memenuhi kriteria sangat baik dan baik, maka hal ini menunjukkan bahwa perangkat pembelajaran praktis. Contoh perangkat pembelajaran dan penilaian yang dikembangkan terlihat pada gambar 2 berikut.

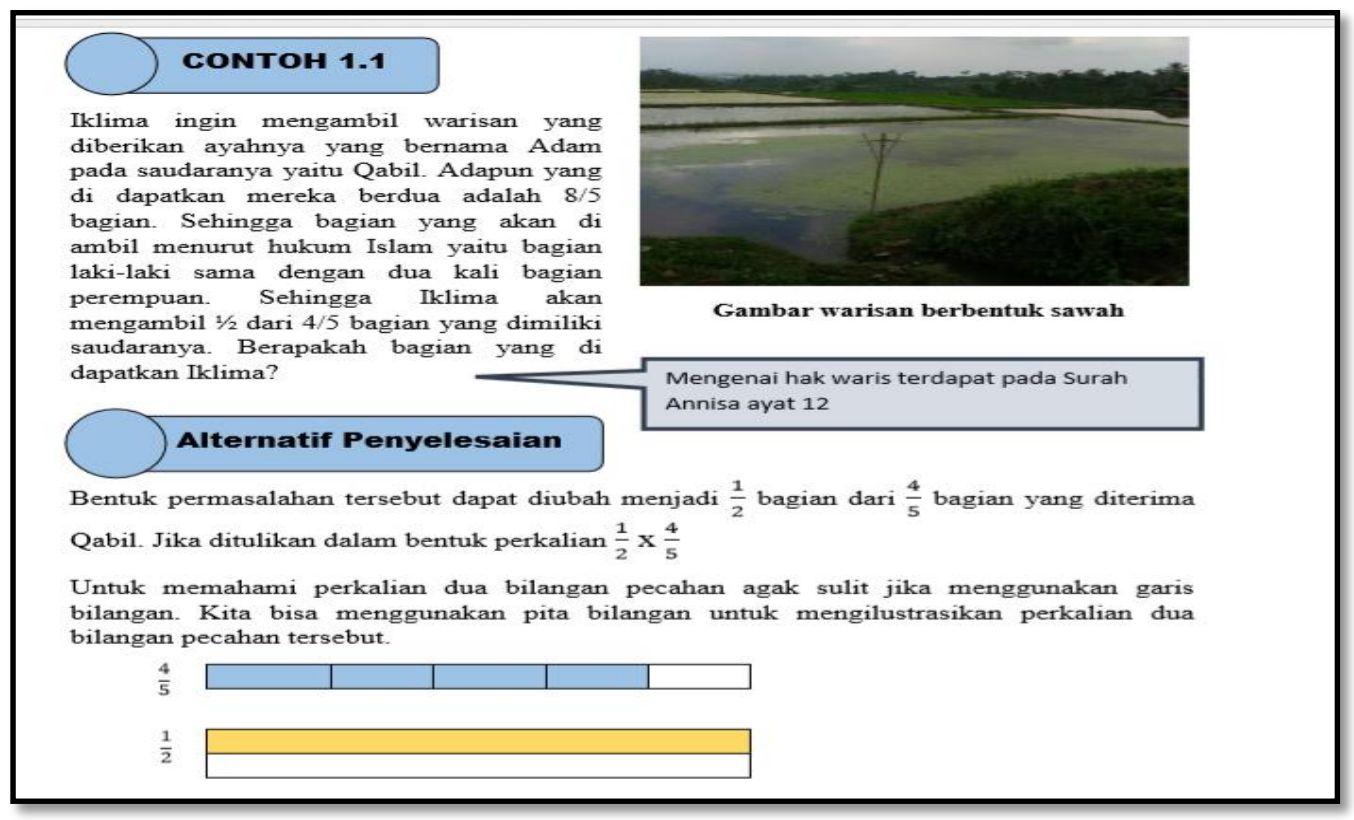

Gambar 2. Contoh perangkat pembelajaran dan penilaian

Analisis keefektifan dilakukan menggunakan analisis MANOVA. Setelah melakukan uji manova, untuk lebih meyakinkan hasil penelitian, dilakukan menggunakan uji T-test untuk mengetahui apakah penggunaan perangkat pembelajaran dan penilaian matematika yang dikembangkan lebih efektif dibanding penggunaan perangkat pembelajaran dan penilaian matematika yang dibuat oleh guru ditinjau dari hasil belajar peserta didik dan angket motivasi siswa. Hasil analisis menggunakan SPSS menunjukkan bahwa $\mathrm{H}_{0}$ ditolak dan Ha diterima yang artinya penggunaan perangkat pembelajaran dan penilaian matematika berbasis budaya islam lebih efektif dibanding penggunaan perangkat pembelajaran dan penilaian matematika yang dibuat oleh guru ditinjau dari hasil belajar dan angket motivasi belajar siswa. Sehingga dapat disimpulkan bahwa perangkat pembelajaran dan penilaian memenuhi kriteria valid, praktis, dan efektif.

Berdasarkan ulasan di atas dapat disimpulkan bahwa terdapat beberapa kelebihan dalam perangkat pembelajaran yang dibuat yaitu perangkat pembelajaran dan penilaian yang dikembangkan merupakan perangkat yang baru dalam proses pendidikan, karena masalah-masalah yang diungkapkan dalam perangkat pembelajaran dan penilaian tersebut semuanya tentang masalah Islami yang dialami dalam kehidupan sehari-hari. Selain itu metode yang digunakan juga 
sesuai dengan tuntutan kurikulum yang berlaku saat ini yaitu menggunakan pendekatan Contextual Teaching and Learning, pendekatan ini sangat berpengaruh terhadap motivasi dan hasil belajar siswa, hal ini diperkuat oleh hasil penelitian yang dilakukan oleh Setyawan dan Leonard (2017) yang menyatakan bahwa pembelajaran menggunakan metode CTL mempunyai pengaruh yang sangat tinggi dalam meningkatkan hasil belajar siswa dilihat dari nilai yang didapatkan siswa dan persentase ketuntasannya. Selain CTL, juga dihubungkan dengan matematika islami yaitu membelajarkan matematika dengan mengenalkan konsep menggunakan masalah-masalah Islami dalam kehidupan sehari-hari siswa.

Kajian Abdussakir dalam Al-khwarizmi (2016) mengatakan bahwa matematika dengan ilmu keislaman mempunyai kaitan yang sangat erat, karena alam kehidupan sehari-hari kita tak lepas dari dari matematika. Selain itu dalam matematika juga dapat kita integrasikan konteks-konteks Islam di dalamnya sehingga siswa dapat mengetahui hubungan matematika dengan Islam tersebut. Pendekatan Islami ini sangat baik untuk meningkatkan motivasi siswa terutama di sekolah Islam seperti pondok pesantren seperti yang dilakukan oleh Salafudin (2015) dalam penelitiannya yang berjudul "Pembelajaran Matematika yang Bermuatan Nilai Islam", di sana Salafudin mengungkapkan pentingnya pembelajaran matematika yang berbasis Islami untuk meningkatkan motivasi siswa untuk belajar matematika, dan merubah anggapan siswa yang mengatakan matematika sulit menjadi mudah. Selain itu dengan bahan ajar ini guru bukan hanya dapat mengajarkan pengetahuan tentang matematika namun juga bisa mengajarkan pengetahuan Islam karena banyak diselipkan Ayat Suci Al Qur'an, hukum Islam, hadist dan nama tokoh Islam. Karena itu siswa dapat termotivasi dan dengan itu mampu meningkatkan hasil belajarnya. Berdasarkan hasil penelitian Hamdi (2014) menunjukkan bahwa motivasi memiliki pengaruh yang positif dan signifikan terhadap peningkatan prestasi belajar matematika.

Langkah terakhir adalah penyebaran. Tahap ini bertujuan untuk penyebaran perangkat pembelajaran dan penilaian pada skala yang lebih luas. Perangkat pembelajaran dan penilaian yang sudah layak pakai atau memenuhi kriteria valid, praktis, dan efektif selanjutnya bisa digunakan dikelas lain oleh guru.

\section{SIMPULAN}

Hasil penelitian dan pengembangan perangkat pembelajaran dan penilaian dengan menggunakan pendekatan Contextual Teaching and Learning (CTL) berbasis budaya Islam yang telah dilakukan di MTs. Hizbul Wathan NW, diperoleh data yang menunjukan bahwa perangkat pembelajaran dan penilaian layak digunakan. Kelayakan produk hasil pengembangan dapat dilihat dari tingkat validitas, reliabilitas, tingkat praktis, dan keefektifan dari perangkat pembelajaran dan penilaian yang dikembangkan. Selain itu, hasil ini juga sebagai bentuk implementasi penilaian autentik dalam penilaian kelas dengan konteks Islam yang sesuai dengan kehidupan sehari-hari siswa dilingkungan pondok pesantren.

\section{DAFTAR PUSTAKA}


Al-Khawarizmi. (2016). Pengembangan modul matematika berbasis kontekstual terintegrasi ilmu keislaman. Jurnal pendidikan matematika dan ilmu pengetahuan alam. Volume 4, Nomor 1, hal. 43-58.

Amri. S, dkk. (2010). Kontruksi pengembangan pembelajaran. Jakarta: Prestasi Pustaka.

Hamdi, S. (2011). Membangun Karakter Siswa Dalam Pembelajaran Matematika Melalui CTL Berbasis Kecerdasan Majemuk. Prosiding Seminar Nasional Matematika dan Pendidikan Matematika UNY

Hamdi, S., \& Abadi, A. M. (2014). Pengaruh motivasi, self-efficacy dan latar belakang pendidikan terhadap prestasi matematika mahasiswa PGSD STKIP-H dan PGMI IAIH. Jurnal Riset Pendidikan Matematika, 1(1), 77-87.

Indrawan, R dan Yaniawati, P (2014). Metodologi Penelitian. Bandung: PT Reflika Aditama.

Johnson, E, B. (2002). Contectual teaching and learning. America: United States.

Kabarpas. (2015). Menag RI: jumlah lembaga pendidikan islam di indonesia terbesar di dunia. Diunduh di http://www.kabarpas.com/menag-ri-jumlah-lembagapendidikan-islam-di-indonesia-terbesar-di-dunia/ tanggal 22 februari 2018.

Kartowagiran, B., Jaedun, A. \& Hamdi, S. (2017). Developing Authentic Assessment Design. International Conference on Ethics of Business, Economics, and Social Science. Yogyakarta State University.

Muhajir, A. (2011). Ilmu pendidikan perspektif kontekstual. Depok: Ar-Ruzz Media.

Permendikbud R.I. Nomor 66 Tahun 2013 tentang Standar Penilaian.

Pip Selaparang. (2014). Jumlah ponpes ntb terbesar di lotim. Diunduh di http://pipselaparang.blogspot.co.id2014/03/jumlah-ponpes-ntb-terbesar-dilotim.html?m=1 tanggal 12 Maret 2018.

Salafudin. 2015. Pembelajaran Matematika yang Bermuatan Nilai Islam. Jurnal Penelitian Vol.12, No. 2, November 2015. hh. 223-243. STAIN Pekalongan.

Setyawan, A \& Leonard (2017) Pengaruh model pembelajaran contextual teaching and learning (CTL) terhadap hasil belajar matematika. Prosiding Diskusi Panel Nasional Pendidikan Matematika. Fakultas Teknik, Matematika, dan Ilmu Pengetahuan Alam Universitas Indraprasta PGRI. ISSN 2581-0812. http://journal.lppmunindra.ac.id/index.php/repository/article/view/1954

Suprihatiningrum, J. (2016). Strategi pembelajaran: teori \& aplikasi. Jogjakarta: ArTruzz Media.

Wardoyo, S.,M. (2013). Pembelajaran kontruktivisme. Bandung: Alfabeta. 